\title{
The Effect on Diesel Injector Wear, and Exhaust Emissions by Using Ultralow Sulphur Diesel Blending with Biofuels
}

\author{
De-Xing Peng \\ Department of Vehicle Engineering, Army Academy, Taiwan, R.O.C.
}

To extend the engine life and to reduce exhaust pollution in diesel engines, lubrication properties were compared between the biodiesel blends and pure petroleum diesel. The biodiesel was used as lubricating additives on pure petroleum diesel at five different concentrations of 0 mass $\%$, 10 mass $\%, 20$ mass $\%, 50$ mass $\%$ and 100 mass $\%$, biodiesel blends were named B0, B10, B20, B50 and B100 biodiesel blends, respectively.

The analysis was performed in three steps. First, the injection of biodiesel in the diesel engine channel was simulated. Second, tribological experiments were performed using ball-on-ring contact method. The wear scar diameters and wear surfaces of the tribopairs were then analyzed. The third step was comparison of biodiesel blends and pure petroleum diesel in terms of engine exhaust emitted by a turbocharged diesel engine.

The wear experiments showed that a small addition of biodiesel to pure petroleum diesel can considerably reduce friction and wear under boundary lubrication. The third tests apply four biodiesel fuel additives on the engine performance, and exhaust emissions results are compared to the baseline (pure petroleum diesel) case. Results show that the fuel consumption is increased by $11.8 \%$ for the biodiesel case, the engine combustion temperature can be increased by $2.49 \%$ for the biodiesel case; the $\mathrm{O}_{2}$ emission can be increased by $12.85 \%$; smoke emissions can be reduced up to $15.89 \%$. Thus, the biodiesel additives can be applied in the diesel fuel to upgrade the engine performance. [doi:10.2320/matertrans.M2014410]

(Received November 17, 2014; Accepted February 3, 2015; Published April 25, 2015)

Keywords: biodiesel, diesel engine, lubrication, wear testing

\section{Introduction}

The world is presently confronted with the twin crises of fossil fuel depletion and environmental degradation. Indiscriminate extraction and lavish consumption of fossil fuels have led to reduction in underground-based carbon resources. The reduced availability of energy resources has forced many governments to develop new energy sources to ensure continued national economic growth. Since petroleum oil is expected to be exhausted within 40 years, annual increases in oil prices are expected in the near future. Recent increases in crude oil prices, limited fossil fuel resources, and environmental concerns have renewed interest in the use of biodiesel produced from vegetable oils and animal fats. ${ }^{1)}$

Because the transportation and agricultural sectors are among the major consumers of fossil fuels, they are the biggest contributors to environmental pollution. Therefore, pollution can be reduced by replacing mineral-based fuels with renewable biofuels. Of the many different potential biofuels, biodiesel has attracted the most interest. Recent concerns over the environmental impact of diesel-powered machinery have driven various countries to legislate reductions in vehicle exhaust emission levels and changes to diesel fuel quality. To meet the requirements of reduced exhaust emissions, automakers have begun to explore alternative fuels such as biofuel. Therefore, to promote the use of biofuel, the performance and lubricity characteristics of biofuel blends used in a diesel engine must be evaluated. ${ }^{2-6)}$

For tribologists, continuing challenges in engine design include reduced emissions and increased operating temperatures. The resulting engine systems must also meet the strict emissions and fuel economy targets that have been recently established. ${ }^{7)}$ One of the main factors in the durability and tribological behavior of engine components and lubricants is fuel characteristics. ${ }^{8)}$ New engines tend to require improved diesel fuel lubricity to avoid excessive wear of the fuel injection system. ${ }^{9)}$ Combustion engine emissions are a major contributor to air pollution in urban areas. Vehicle emissions can be classified as regulated and unregulated pollutants. Regulated pollutants are carbon monoxide (CO), nitrogen oxides $\left(\mathrm{NO}_{x}\right)$, and unburned fuel or partly oxidized $\mathrm{HC}$. The $\mathrm{CO}$ is a toxic combustion product resulting from incomplete combustion of hydrocarbons. ${ }^{10)}$ In the presence of sufficient oxygen, $\mathrm{CO}$ is converted into $\mathrm{CO}_{2}$. Since biodiesel is an oxygenated fuel, its combustion is more complete, which reduces $\mathrm{CO}$ emissions in the exhaust. ${ }^{11)}$ Biofuels are a feasible solution to the global petroleum crisis. Gasoline and diesel engines are the major sources of greenhouse gas (GHG) emissions. Scientists throughout the world are exploring various alternative energy resources to quench the everincreasing energy demands of the global population. ${ }^{12,13)}$

Biodiesel is a clean burning mono-alkyl ester-based oxygenated fuel made from natural, renewable sources such as new/used vegetable oils and animal fats. ${ }^{14)}$ Although biodiesel contains no petroleum products, its main characteristics are similar to those of conventional diesel. Therefore, it can be blended in any proportion with mineral diesel to create a stable biodiesel blend. Many countries are seeking alternative fuels for diesel engines. So far, biodiesel is one of the alternative fuels being promoted. The search for alternative fuels is motivated by the goals of sustainable development, energy conservation, efficiency and environmental preservation.

Because biodiesel does not contain sulfur, it generates lower sulfate emissions and particulate matter compared to conventional fuels. The near absence of sulfur in biodiesel can help to reduce the problem of acid rain resulting from use of transportation fuels. The lack of aromatic hydrocarbon (benzene, toluene etc.) in biodiesel also reduces unregulated emissions such as ketone and benzene. Breathing particulate is a known human health hazard, especially in terms of respiratory system problems. The PM released by diesel 
engines includes elemental carbon, metals, and other substances.

Interest in diesel fuel lubricity has escalated since the early 90 s. It was at this time that ultra low sulfur diesel fuel $(<50 \mathrm{ppm})$ (ULSDF) was commercialized, and coincident with this, there was increased incidence of drivability problems and pump failures. The inherent lubricity of ultra low sulfur diesel fuels proved to be unacceptable. Karaosmanoglu et al. ${ }^{15)}$ studied the effects of biodiesel on engine behavior over a 50-h period and observed no remarkable changes. The results were considered promising for this fuel although diesel engines are expected to last much longer than $50 \mathrm{~h}$.

The many studies of the effects of biodiesel on engine performance consistently show slightly decreased torque and power with increased specific fuel consumption. Although reported emission results for biofuels vary, most studies report lower $\mathrm{CO}, \mathrm{HC}$ and smoke emissions and higher $\mathrm{NO}_{x}$ emissions. Some studies have focused on engine wear resulting from the use of vegetable oils and its transesterified form. Since biodiesel improves combustion, combustion chamber temperature and oxygen are expected to increase. Therefore, biodiesel-fueled engines have increased $\mathrm{NO}_{x}$ emissions. ${ }^{16,17)}$ Pramanik et al. ${ }^{18)}$ found that a $50 \%$ blend of jatropha oil can be used in diesel engines with no major operational difficulties. However, further studies of the longterm durability of the engine are needed.

These reductions in exhaust emissions have caused changes in engine design for biofuel use and control of the fuel injector system. Therefore, in making an attempt to promote the use of biodiesel, is important to evaluate the performance and lubricity characteristics of biofuel-diesel fuel blends used in a diesel engine. Although many studies have confirmed acceptable performance results for engines operating with biofuels, very few have performed a long-term analysis of wear and maintenance. The popularity of diesel engines has increased in the recent years due to their high fuel efficiency and the low emissions. ${ }^{19-32)}$ However, the durability and tribological behaviors of the fuel injection components of an engine that runs on biodiesel are unclear. The tribological a percentage mix in pure petroleum diesel are studied using a ball-on-ring wear tester in order to find the optimal concentration, and the mechanism of the reduction of wear and friction will be investigated by optical microscopy (OM) and scanning electron microscopy (SEM).

\section{Experimental}

This study investigated the fuel tribological properties, engine performance and emissions of biodiesels and pure petroleum diesel. A biodiesel additive was added to ultra low sulfur diesel fuel (less than $50 \mathrm{ppm}$ ) at weight percentages of 0 mass $\%, 10$ mass $\%, 20$ mass $\%, 50$ mass $\%, 100$ mass $\%$ (labeled as B0, B10, B20, B50 and B100). The essential fuel properties are given in the Table 1. First, the tribological behavior of the injection system of a diesel engine using biodiesel blends was investigated. All biodiesels were reinjected without burning process after a filtering treatment (Fig. 1). The average roughness $\left(R_{\mathrm{a}}\right)$ of the needle surface was measured to evaluate the tribological behavior of testing
Table 1 Base fuel properties.

\begin{tabular}{lccccc}
\hline \multicolumn{1}{c}{ Property } & B0 & B10 & B20 & B50 & B100 \\
\hline Viscosity $\left(40^{\circ} \mathrm{C}, \mathrm{Cst}\right)$ & 2.62 & 2.83 & 3.06 & 3.52 & 4.54 \\
Flash point $\left({ }^{\circ} \mathrm{C}\right)$ & 88 & 93 & 104 & 121 & 162 \\
Sulphur content $(\%)$ & 0.01 & $<0.01$ & $<0.01$ & $<0.01$ & $<0.01$ \\
Water content $(\mathrm{ppm})$ & 50.2 & 155.3 & 178.9 & 210.3 & 250.4 \\
Cetane number & 52.3 & 52.3 & 52.2 & 52.5 & 52.6 \\
\hline
\end{tabular}

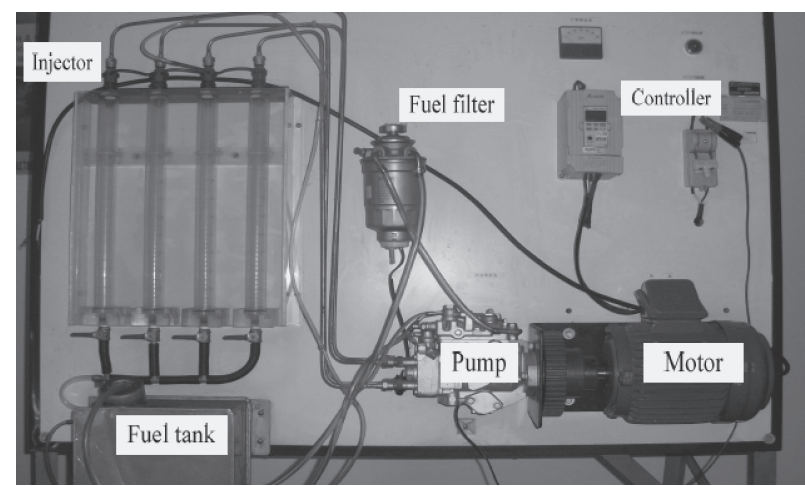

Fig. 1 Experimental set-up of the injection system of a diesel engine testing system.

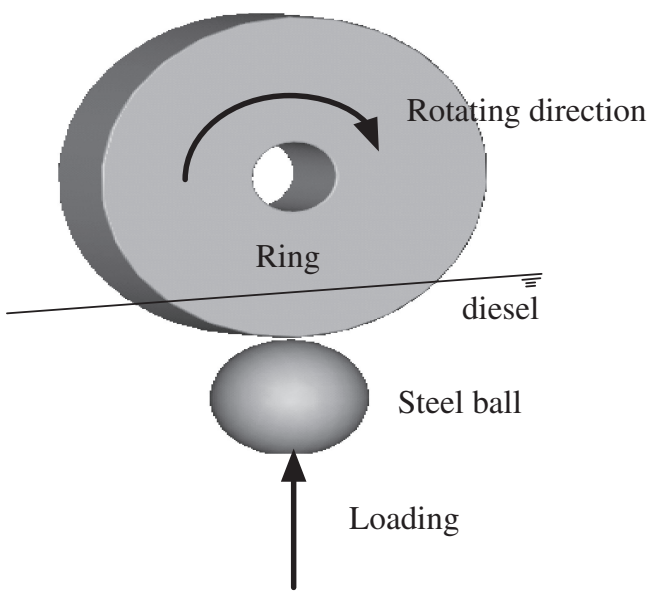

Fig. 2 A schematic drawing of the ball-on-ring apparatus.

in various biodiesel. The roughness of the needle was measured before and after testing using a surface profiler. Next, the tribological behavior of the fuel injection plunger was simulated with a tribology friction ball-on-ring test.

The tribology wear tests used the ball-on-disk contact method with three different loads $(30 \mathrm{~N}, 50 \mathrm{~N}, 70 \mathrm{~N}$ and $90 \mathrm{~N})$ forcing a stationary ball against a rotating ring, forming the tribo contact (Fig. 2). The ring was made of bearing steel (AISI 52100 steel with HRc of 60-62, of composition: $0.95-1.05 \%$ C, $0.15-0.35 \% \mathrm{Si}, 0.2-0.4 \% \mathrm{Mn},<0.027 \% \mathrm{P}$, $<0.020 \% \mathrm{~S}, 1.3-1.65 \% \mathrm{Cr},<0.3 \% \mathrm{Ni}$, and $<0.25 \% \mathrm{Cu}$ ) with $70 \mathrm{~mm}$ diameter and thickness of $17 \mathrm{~mm}$. The ball used in this study was made of bearing steel GCr15 with hardness of HRc 59-61 and diameter of $12.7 \mathrm{~mm}$. Both surfaces were polished to roughness $R_{\mathrm{a}}=0.05 \mu \mathrm{m}$ for ball and $R_{\mathrm{a}}=0.20$ $\mu \mathrm{m}$ for ring. The mean diameter of wear scar on the ball was then measured from five identical tests using a digital-reading 


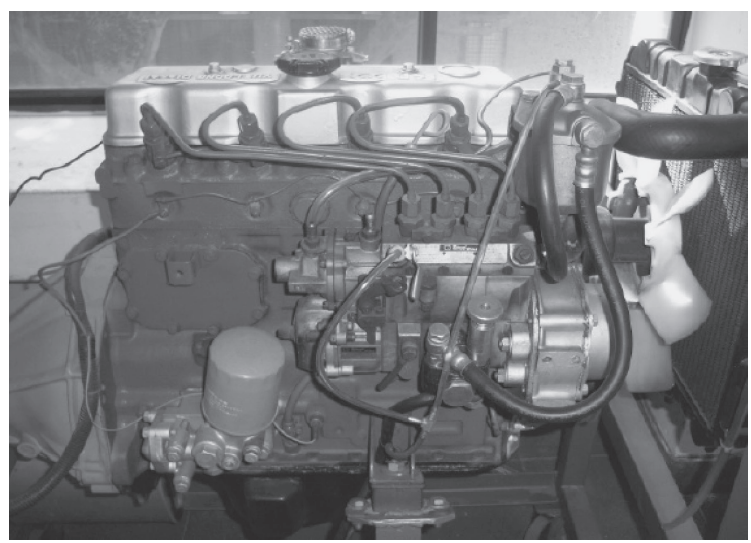

Fig. 3 Experimental set-up of the diesel engine testing system.

microscope with accuracy of $0.01 \mathrm{~mm}$. The ball-on-ring method is used to assess lubricity of fuel oils and fuels containing biodiesel additives. The concentrated contact is used in the ball-on-ring system. Typical measurement parameters defined in the PN-EN ISO 12156 standard were applied. The steel balls were rinsed in ethanol immediately and then the topography of the scar surfaces after the wear test was observed by OM and SEM.

The third step was comparing biodiesel and petroleum diesel in terms of performance in a turbocharged diesel engine. The water-cooled diesel engine used in the engine test had a 4-cylinder four-stroke engine with direct injection (Fig. 3). To examine the emission characteristics, a portable SINCRO exhaust gas analyzer (model EGA2001C) was used to measure the concentration of exhaust gases of the test engine such as hydrocarbon (HC) in part per million (ppm), dioxide $\left(\mathrm{O}_{2}\right)$ in percentage volume (\%vol) and exhaust gas temperature $\left({ }^{\circ} \mathrm{C}\right)$.

\section{Results and Discussion}

The study was performed in the following three steps.

\subsection{Injection system simulation}

The first tests compared petroleum diesel and a biodiesel blend in terms of friction produced in a fuel-injector operating for $400 \mathrm{~h}$. The fuel injection plunger was made of bearing steel with $6 \mathrm{~mm}$ diameter and length of $35 \mathrm{~mm}$. The injector plunger surfaces were also evaluated in terms of wear and surface roughness. Table 2 show the injector plunger surface roughness analysis results. Average roughness $\left(R_{\mathrm{a}}\right)$ determined through a surface profiler decreased from 0.453 $\mu \mathrm{m}$ to $0.335 \mu \mathrm{m}$ after biodiesel usage, which indicated improved lubrication. The findings indicate that the biodiesel and biodiesel blend obtained a normal rate of wear on the engine injector plunger. Figure 4 shows that the injector plunger surface had no corrosion, scuffing or high wear.

\subsection{Ball-on-ring test}

The wear scar diameter and friction force of the additive concentration of biodiesel in pure petroleum diesel are obtained by tribological ball-on-ring test and shown in Fig. 5, which indicates that adding biodiesel to petroleum diesel can reduce the wear scar diameter of steel balls in comparison
Table 2 Comparison of different additive concentrations of biodiesel in pure petroleum diesel in terms of effects on injector plunger surface roughness.

\begin{tabular}{ccccccc}
\hline & new & B0 & B10 & B20 & B50 & B100 \\
\hline $\begin{array}{c}\text { Injector plunger surface } \\
\text { roughness }(\mu \mathrm{m})\end{array}$ & 0.453 & 0.371 & 0.364 & 0.348 & 0.337 & 0.335 \\
\hline
\end{tabular}

(a)

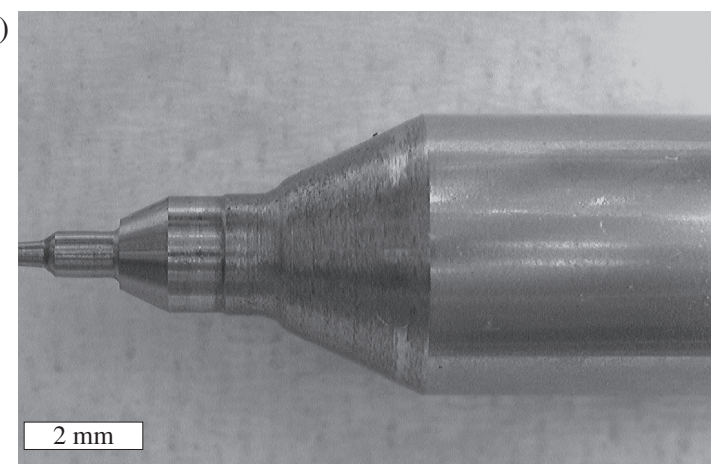

(b)

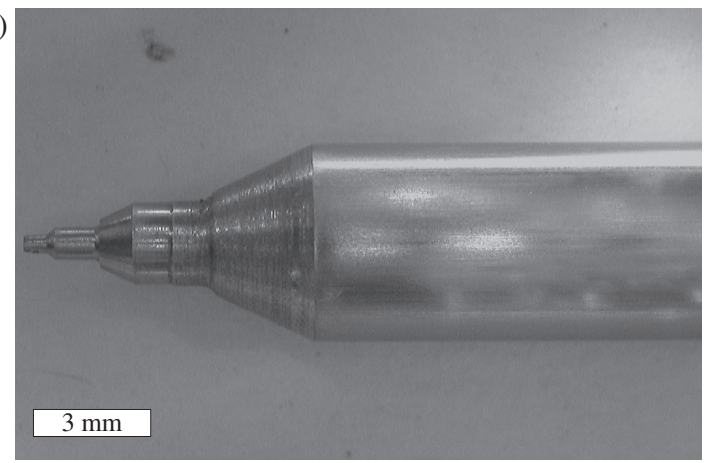

(c)

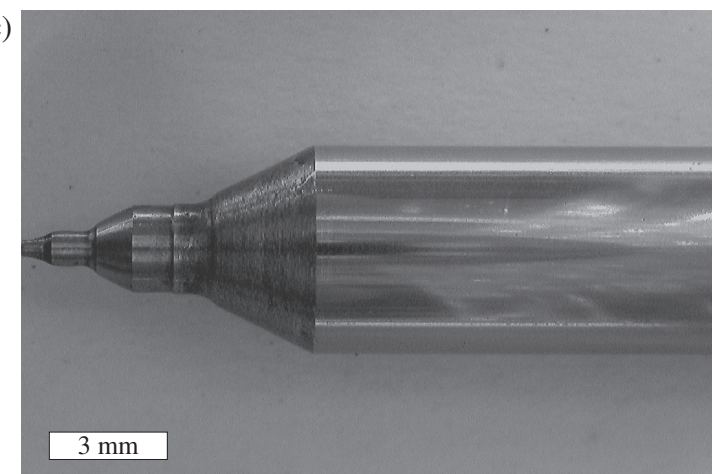

Fig. 4 Optical microscopy micrographs of injector plunger surface (injection system, $500 \mathrm{rpm}, 400$ hour); (a) new injector, (b) pure petroleum diesel, (c) petroleum diesel added by 50 mass $\%$ biodiesel.

with pure petroleum diesel. Overall, biodiesel-ULSDF fuel blends appear to be better lubricants at all concentrations, possibly due to their higher polarity. The optimal concentration of biodiesel in terms of minimizing wear scar diameter and friction force is 20 mass $\%$. The fuel properties analysis results showed that the benefits of biodiesel include a high cetane value, extremely low sulfur and aromatic contents, and good lubricity. The molecules in biodiesel are primarily fatty acid methyl ester compound. It has a higher dynamic viscosity than petroleum diesel and is similar to surface active agents having a higher affinity with metal. It can be used as oil additives and enhance the lubricant, and reduce wear. 


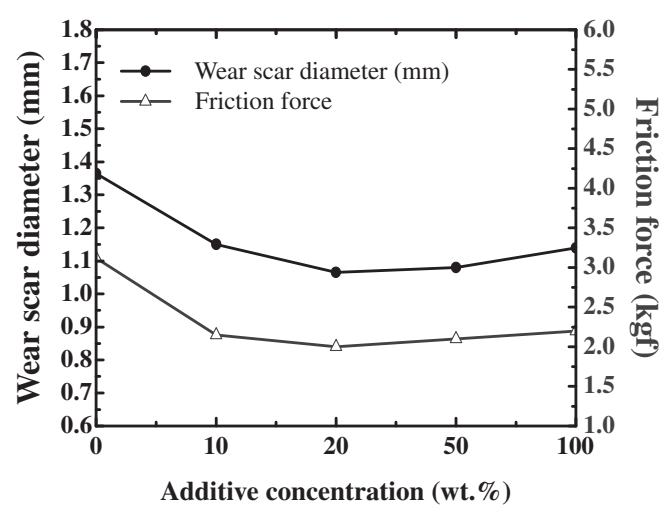

Fig. 5 Wear scar diameter and friction force related to the additive concentration of biodiesel in pure petroleum diesel (ball-on-ring, $500 \mathrm{rpm}$, $\left.R_{\mathrm{a}}: 0.20 \mu \mathrm{m}, 50 \mathrm{~N}, 120 \mathrm{~min}\right)$.

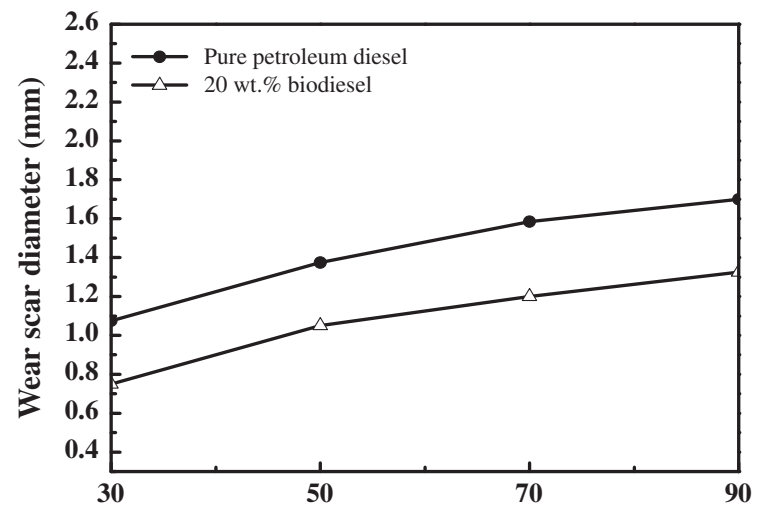

Fig. 6 Comparison of wear scar diameter related to applied load for pure petroleum diesel and petroleum diesel containing biodiesel (ball-on-ring, $\left.500 \mathrm{rpm}, R_{\mathrm{a}}: 0.20 \mu \mathrm{m}, 120 \mathrm{~min}\right)$.

The variations of the wear scar diameter for various loads for pure petroleum diesel and petroleum diesel adding 20 mass \% biodiesel are shown in Fig. 6. This figure indicates that the wear scar diameter of the ball increases with the applied load for both fuels. In using pure petroleum diesel, the diameter of wear scar increases sharply as applied load increases. However, for the usage of petroleum diesel adding 20 mass\% biodiesel the wear scar diameter of the ball subjected to the same applied load has the stable increasing. A slight mass \% of biodiesel exhibits improved load capacity wear resistance. Analysis of lubricity characteristics of the biodiesel fuel blends showed a nonlinear relationship between biodiesel concentration and wear loads. Compared to pure petroleum diesel, petroleum diesel adding slight biodiesels has better tribological properties in terms of loadcarrying capacity, antiwear and friction-reduction.

Figure 7(a)-(c) shows the worn surfaces of the ball specimens tested at room temperature $\left(30^{\circ} \mathrm{C}\right)$ for the biodiesel blends. Figure 7(b), (c) showed that the wear scar surfaces exposed to the 20 and $50 \%$ biodiesel contaminated lubricant appeared much smoother, which reduced material transfer. The percentage share of the lubricant film covering the surface under friction conditions increases as concentration increases. The protective films can reduce thermal energy in sliding contact and thereby improve lubricity. These lubricity enhancing films are most likely carboxylic acid moiety based. The above experimental results are (a)

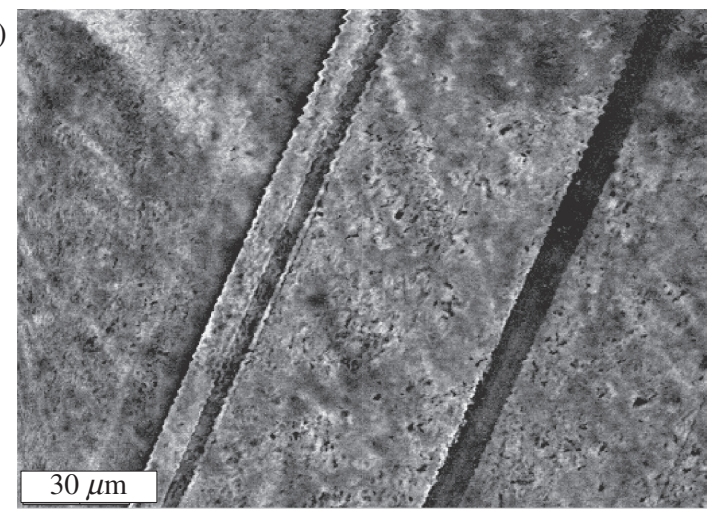

(b)

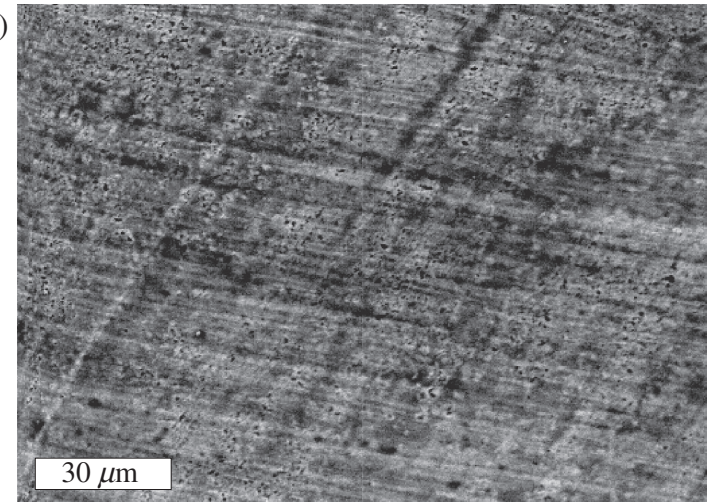

(c)

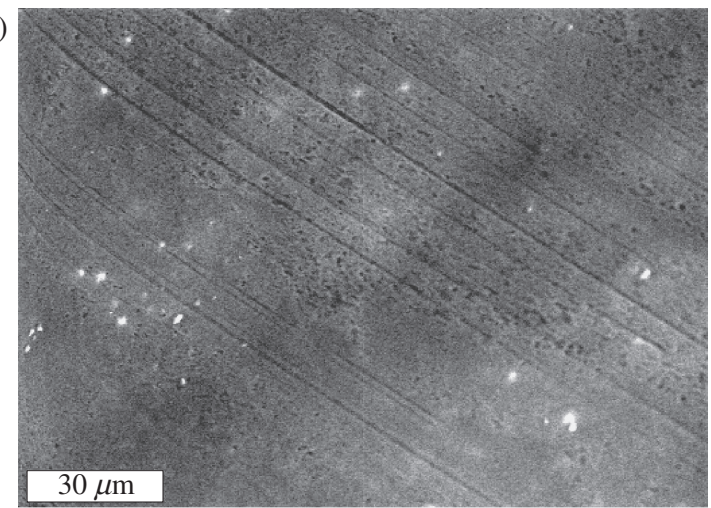

Fig. 7 SEM micrographs of worn surfaces (ball-on-ring, $500 \mathrm{rpm}, R_{\mathrm{a}}: 0.20$ $\mu \mathrm{m}, 50 \mathrm{~N}, 120 \mathrm{~min}$ ); (a) pure petroleum diesel, (b) petroleum diesel added by 20 mass \% biodiesel, (c) petroleum diesel added by 50 mass $\%$ biodiesel.

attributable to biodiesel contamination acting as a friction reducing additive in pure petro-diesel. Its strong affinity for metal surfaces causes it to form a strong additional monolayer or chemical coating between moving surfaces, which substantially reduces wear tendencies. Figure 8 show the steel ring surface roughness analysis results. The surface exposed to pure petro-diesel after the lubricity test revealed a residue at the wear scar periphery and had a surface roughness of $0.565 \mu \mathrm{m}$. Average roughness $\left(R_{\mathrm{a}}\right)$ determined through a surface profiler decreased from $0.531 \mu \mathrm{m}$ to $0.304 \mu \mathrm{m}$ after biodiesel usage, which indicated improved lubrication. The surface roughness analysis also showed good results. A possible reason is that the additional lubricity properties of the biodiesel reduced friction.

\subsection{Engine performance test}

The third test uses four biodiesel mass $\%$ concentration $(10 \%, 20 \%, 50 \%$ and $100 \%)$ in the engine, comparing engine performance and exhaust emissions with the baseline (pure 


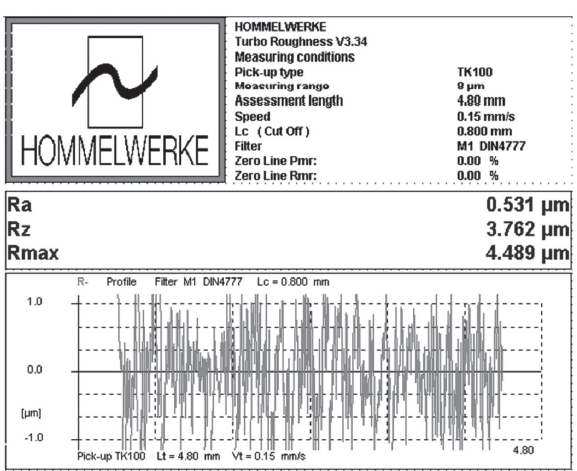

(a) Profiles across the new steel ring

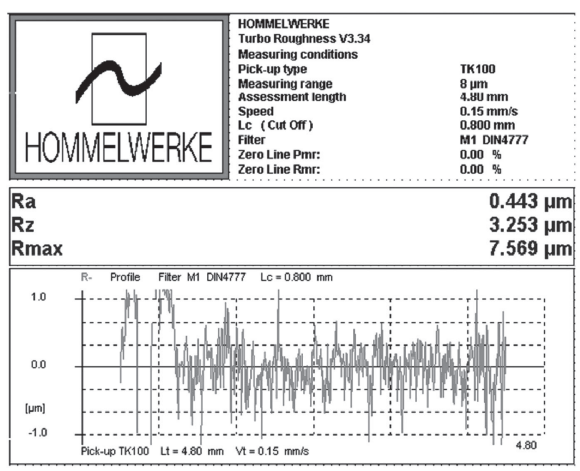

(c) Petro-diesel added by $10 \mathrm{wt} . \%$ biodiesel

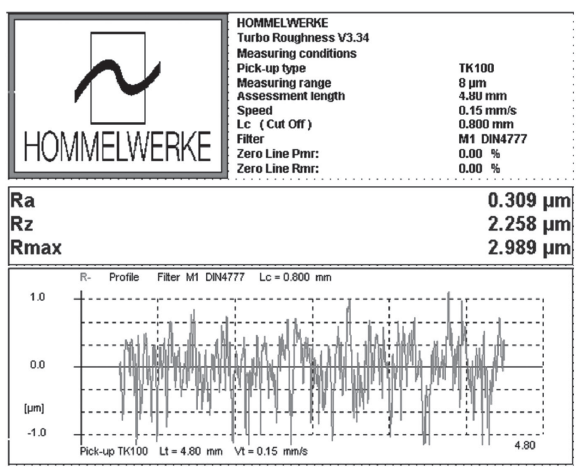

(e) Petro-diesel added by 50 wt. $\%$ biodiesel

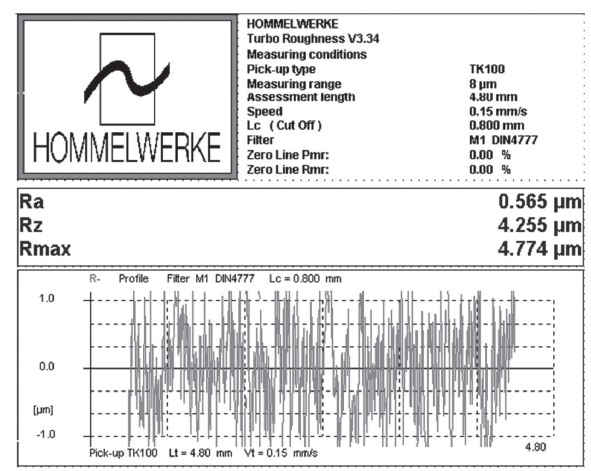

(b) Rubbed surface lubricated by pure petro-diesel.

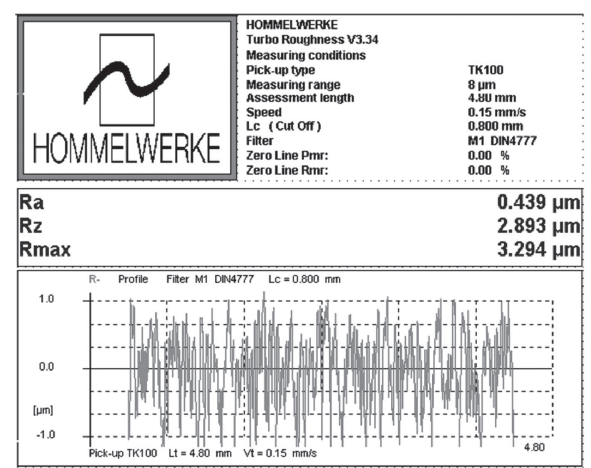

(d) Petro-diesel added by $20 \mathrm{wt} . \%$ biodiesel

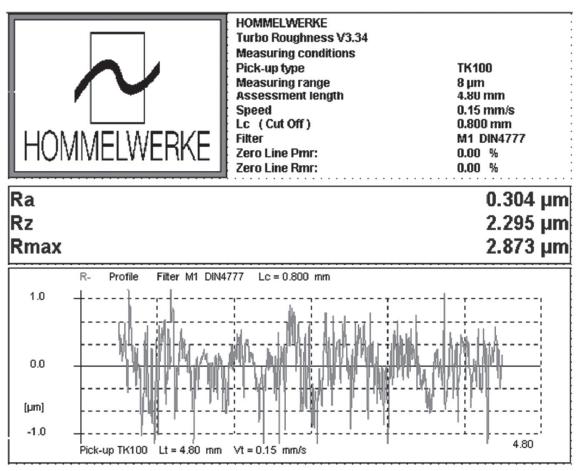

(f) Petro-diesel added by 100 wt.\%

biodiesel

Fig. 8 Roughness of the steel ring surface and rubbed surface after wear test. (500 rpm, $50 \mathrm{~N}, 120 \mathrm{~min}$ ).

petroleum diesel) case. Figures 9-12 shows that the fuel consumption is increased by $11.8 \%$ for the biodiesel case, the engine combustion temperature can be increased by $2.49 \%$ for the biodiesel case; the $\mathrm{O}_{2}$ emission can be increased by $12.85 \%$; smoke emissions can be reduced by a maximum of $15.89 \%$. Biodiesel fuel has higher fuel consumption than diesel fuel but can reduce smoke. It is too low a calorific value to increase fuel consumption. Due to the high cetane number and oxygen concentration of biodiesel, combustion speeds improved hence thus reducing smoke. Oxygen concentration of biodiesel is very high, the combustion is more complete, increasing combustion efficiency and resulting in higher combustion temperatures. The experimental results suggest that adding biodiesel into petroleum diesel decreases engine smoke emissions, which are known human health hazards.

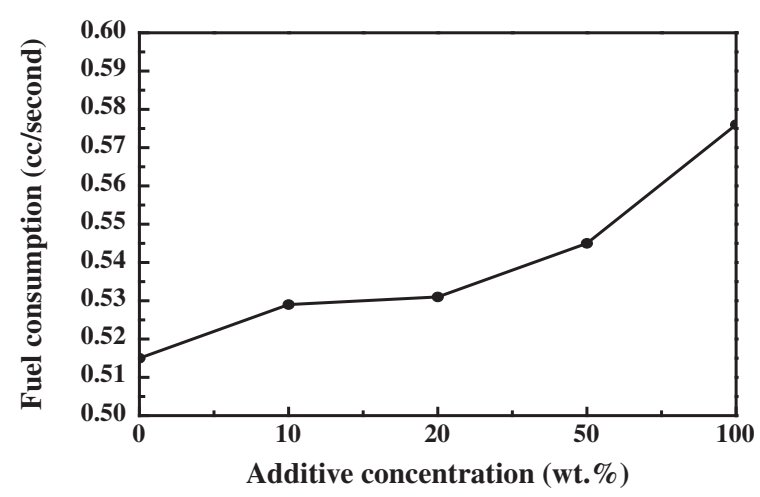

Fig. 9 Fuel consumption as a function of the additive concentration of biodiesel in pure petroleum diesel. 


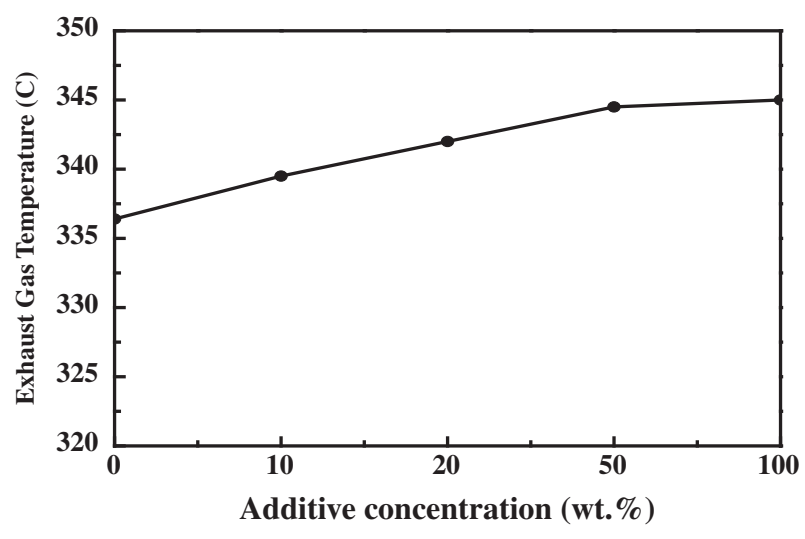

Fig. 10 Exhaust gas temperature as a function of the additive concentration of biodiesel in pure petroleum diesel.

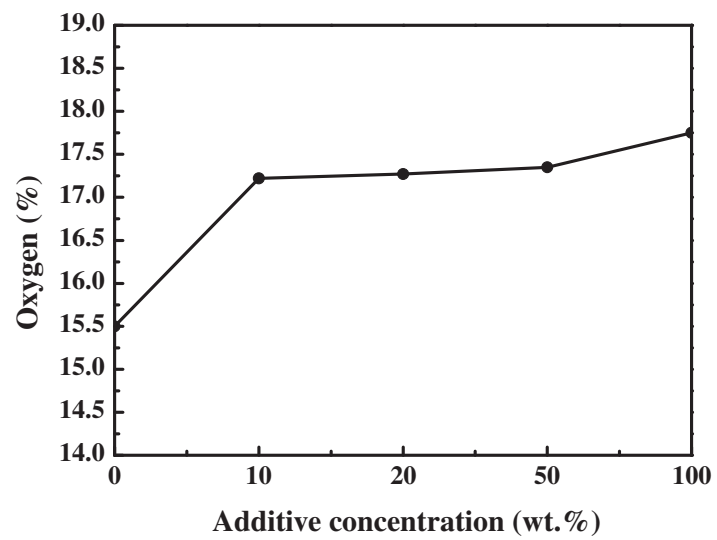

Fig. 11 Oxygen as a function of the additive concentration of biodiesel in pure petroleum diesel.

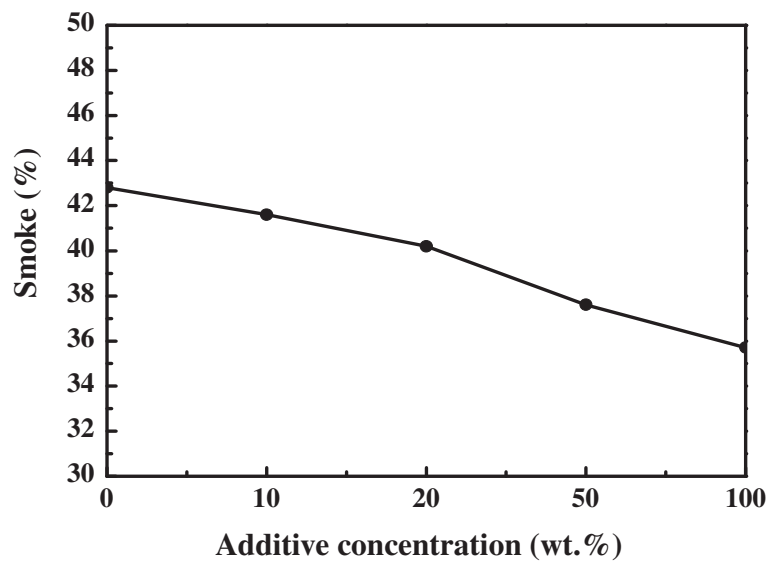

Fig. 12 Hydrocarbon as a function of the additive concentration of biodiesel in pure petroleum diesel.

Prior studies show that adding a small amount of biodiesel to pure petroleum diesel fuel considerably reduces friction and wear under boundary lubrication. All concentrations of biodiesel blends are apparently better lubricants, possibly due to their better polarity. Using biodiesel as a fuel additive in pure petroleum diesel fuel improves engine performance and exhaust emissions.

\section{Conclusion}

(1) Experiments showed that, compared to pure petroleum diesel, biodiesel produced much lower smoke emissions from a 4-stroke diesel engine. This is also due to oxygenated nature of biodiesel where more oxygen is available for burning and reducing smoke emissions in the exhaust.

(2) Experimental results have been shown that the biodiesel blends could improve the lubricity performance of pure petroleum diesel fuel effectively under all testing conditions.

\section{Acknowledgement}

This work was supported by the National Science Council of the R. O. C. with grant no. NSC 101-2221-E-539-003.

\section{REFERENCES}

1) G. Bantchev and G. Biresaw: Lubrication Sci. 20 (2008) 283-297.

2) N. Nabi, M. Z. Shahadat, S. Rahman and R. A. Beg: SAE Paper, 01 (2004) 30-34.

3) M. S. Graboski and R. L. McCormick: Progr. Energy Combust. Sci. 24 (1998) 125-134.

4) L. Dong, X. Liang and G. Shu: Lubrication Sci. 25 (2013) 429-478.

5) O. O. Ajayi, M. F. Alzoubi, A. Erdemir and G. R. Fenske: Tribol. Trans. 51 (2008) 298-304.

6) J. P. Szybist and A. L. Boehman: SAE Technical Paper (2003) 10391045.

7) B. Yin, X. Li, Y. Fu and W. Yun: Lubrication Sci. 24 (2012) 293-312.

8) P. V. Joseph and D. K. Sharma: Lubrication Sci. 22 (2010) 149-161.

9) Q. Jun, J. John, P. J. Truhan, A. Blau and O. Ronald: Tribol. Trans. 54 (2010) 50-57.

10) S. Furuhama, M. Suzuki, H. Ishikawa and T. Watanabe: Tribol. Trans. 34 (1991) 86-92.

11) F. Gili, A. Igartua, R. Luther and M. Woydt: Lubrication Sci. 23 (2008) 313-330.

12) D. G. Kesse: J. Petroleum Sci. Eng. 26 (2000) 157-168.

13) X. Cao: Resour. Policy 29 (2003) 61-74.

14) M. T. Siniawski, N. Saniei and P. Stoyanov: Lubrication Sci. 23 (2011) 301-311.

15) F. Karaosmanoglu, G. Kurt and T. Ozaktas: Renew. Energy 19 (2000) 219-221.

16) P. R. Wander, C. R. Altafini, A. L. Colombo and S. C. Perera: Energy 36 (2011) 3917-3923.

17) K. R. Kaufman and M. Ziejewski: Trans. ASAE 27 (1984).

18) K. Pramanik: Renew. Energy 28 (2003) 239-248.

19) M. Roegiers and B. Zhmud: Lubrication Sci. 21 (2009) 169-182.

20) I. M. Atadashi, M. Aroua and K. A. Abdul Aziz: Renewable and Sustainable Energy Reviews 14 (2010) 1999-2008.

21) K. R. C. Savita, A. K. Saxena, M. S. Negi, A. K. Bhatnagar, H. B. Goyal and A. K. Gupta: Fuel Processing Technology 88 (2007) 303-307.

22) H. C. T. Ong, M. I. Mahlia, H. H. Masjuki and R. S. Norhasyima: Renewable and Sustainable Energy Reviews 15 (2011) 3501-3515.

23) www.academicjournals.org.

24) R. K. A. Rehman and R. M. Sarviya: Renewable and Sustainable Energy Reviews 16 (2012) 1762-1778.

25) E. Sukjit and K. D. Dearn: Wear 271 (2011) 1772-1777.

26) M. W. Sulek, A. Kulczycki and A. Malysa: Wear 268 (2010) 104-108.

27) A. S. M. A. Haseeb, M. A. Fazal, M. I. Jahirul and H. H. Masjuki: Fuel 90 (2011) 922-931.

28) H. H. Masjuki and M. A. Maleque: Wear 206 (1997) 179-186.

29) A. A. S. M. Haseeb, A. S. Y. Sia, M. A. Fazal and H. H. Masjuki: Energy 35 (2010) 1460-1464.

30) M. Muñoz, F. Moreno, C. Monné, J. Morea and J. Terradillos: Renewable Energy 36 (2011) 2918-2924.

31) B. P. Anand, C. G. Saravanan and A. Srinivasan: Renewable Energy 35 (2010) 1179-1184.

32) M. S. Ejaz and J. Younis: Renewable and Sustainable Energy Reviews 12 (2008) 2484-2494. 